\title{
Approaches to the Economization of Cultural Heritage in Context of Destination Management in the Czech Republic
}

\author{
- Gajdošík Tomás, Hrubcová Gabriela, Šrámek Jan, Tittelbachová Šárka
}

\begin{abstract}
Cultural monuments are one of the strongest stakeholders at the regional level of tourism in the Czech Republic. There is a huge potential for cooperation between destination management and cultural monuments at the regional level. However, these possibilities are not fully established yet. The article is based on the survey conducted among managers of cultural monuments in the selected region of the Czech Republic to demonstrate the importance of cooperation between these two subjects. On the basis of the survey and analysis of the possibilities of cooperation between tourism industry and cultural monuments at the regional level, the new ways of cooperation are recommended.
\end{abstract}

Keywords: Cultural tourism, Monuments, Heritage, Interagency cooperation, Destination management, Economization

JEL Classification: $L 83$

\section{INTRODUCTION}

Travel and tourism industry is an important part of the Czech national economy. According to the data of the World Travel \& Tourism Council (WTTC, 2014), tourism industry contribution to the GDP and the employment is undeniable. Direct contribution to the GDP was $2.9 \%$, indirect contribution $8.4 \%$ in 2013. Nevertheless, its contribution to the employment is even more significant. More than $5 \%$ direct and $10.4 \%$ indirect contribution to the employment indicates its irreplaceable position in the Czech national economy.

One of the reasons why this relatively strong position exists is because of the unique supply of the Czech Republic. Large number of rare immovable cultural monuments, including 12 monuments listed on the UNESCO World Heritage List, can be found in a unique landscape of the Czech Republic. These monuments are very important part of the various destination management institutions offers. Although it is nearly impossible to find a regional destination management company without any cultural monument in its offer, there are still many issues concerning their cooperation for creation a complex tourism product.

The need of an interagency cooperation between cultural and tourism sector is mentioned by many institutions such as the Czech Ministry of Culture (MK ČR, 2011). However, the cooperation between cultural monuments and destination management institutions is far from the ideal.

The article deals with the above-mentioned issue. It presents the research based on the survey 
among cultural monuments managers in the Czech Republic. The main aim was to identify the approaches of these monuments to the creation of cultural tourism products and their involvement to wider activities of respective destinations represented by national or regional destination management organisations. The research is presented after a few theoretical chapters dealing with the importance and functions of destination management, definition of cultural tourism and its potential in the Czech Republic regions. The results are presented on the example of the specific Czech Republic region with high potential for cultural tourism.

\section{THEORETICAL FRAMEWORK}

This part deals with the theoretical framework needed for the complex understanding of the importance of the presented research. First two chapters describe theoretical background of destination management importance and cultural tourism. Next chapter specifies cultural tourism offer of the Czech Republic aimed at the surveyed and analyzed region - the Pilsen region.

\subsection{Destination management}

Tourism destination represented by a resort, tourism region or a country is a target of travelling and stay of tourists. Several stakeholders create tourism product of a destination; therefore the fragmented nature of the product requires a substantial degree of cooperation. The important thing for tourists is the complex product of destination, not the individual tourism facilities. Therefore it is necessary for the destination to act as a tourism package and create a complex tourism product.

Way how to create such complex product is applying a cooperative destination management that can be seen as a central requirement for destination competitiveness on tourism market (Morrison, 2013). Cooperative destination management is a tool for coalition of interests in a destination and it represents a new strategy of cooperation (Gúčik, 2012).

There are several motives why the destination stakeholders act together and support the cooperative destination management. They can be divided into four categories.

a) Strategic motives. The cooperative destination management helps to reach new markets, establishes the competitive advantage of destination and creates synergy effects.

b) Cost-related motives. The outcome of destination cooperation is economies of scale and economies of scope. Cooperation also minimizes costs of new technologies, innovations and marketing communication (Fyall, Oakly \& Weiss, 2000).

c) Information motives. By acting together, destination stakeholders are more informed and they share their know-how easily.

d) Marketing motives. The aim of cooperative management and marketing is a creation of destination product and creating single image of a destination.

These motives explain the main reasons why the destination stakeholders cooperate. The motives are also associated with benefits and cost of cooperation. The benefits of cooperation include the opportunity to learn about the activities of other stakeholders and taking into ac- 
count their views, risk-sharing, strengthening the cohesion of a destination (Nechvílova, Holý \& Krátký, 2006), "more efficient use of resources, increasing the competitiveness through joint planning, brand creation and development of a complex product (Wang \& Fesenmaier, 2007)". Costs of cooperation are related to time and energy. Not including the main stakeholders reduces the effect of cooperation. Cooperation is also "hiding the risks associated with information leakage, the opportunity cost, misuse of cooperation for the benefit of one stakeholder and the risk of lost funds (Palatková, 2011)". The motives, benefits and cost of cooperation create conditions for formation of cooperative destination management and marketing

\section{Destination management organization}

Creating a destination management organization (DMO) is a first step to cooperative destination management. Its role is to coordinate activities under one coherent strategy (UNWTO, 2007). DMO do not control the activities of its partners but brings together resources and undertake marketing activities. Inskeep (1991), Buhalis (2000), Presenza, Sheehan and Ritchie (2005) and Pike (2008) called this organization as a destination marketing organization. However, because of the change in tourism demand and supply, the main task of the organization has change to cooperative management of destination stakeholders a therefore it is nowadays called destination management organization, where the marketing has become the important tool of cooperative management. According to Pechlaner et al. (2012) it acts as a coordinator of stakeholders in tourism destination and Beritelli (2011) ads that the necessity of the mutual trust for effective destination management.

A DMO should define the competitive advantages of a destination by comparing tourism potential of a destination with another destinations and determining the absolute and relative competitive advantage of destination on a global market. This process should be based on continuous marketing research and situational analysis. Porter developed the concept of competitiveness (1990) and defined the factors of competitive advantage. Ritchie and Crouch (2003) adapted these factors to the particularities of tourism destination (Fig 1.)

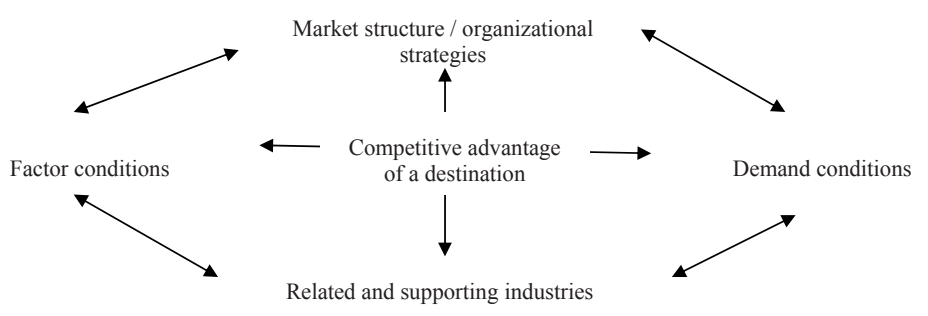

Fig 1 - Factors of competitive advantage of a destination Source: Ritchie \& Crouch, 2003

Competitive advantages of a destination emerge in a dynamic system consisting of four interdependent determinants, which together form a diamond. Factor conditions form destination's position taking into account factors of production necessary to compete in the tourism industry. 
Demand conditions are important factor for creation of tourism products and services. The presence or absence of supplier industries and related industries in the region creates the related and supporting industries. Market structure defines the conditions in the destination governing how companies are created, organized and managed (Vanhove, 2005).

Another task of DMO is a creation of destination marketing strategy and tactics. It is a complex process, because of many independent stakeholders involved. Perhaps the most important challenge for destination management and marketing is to bring all individual partners together to cooperate rather than compete and to create integrated marketing strategy and tactics (Buhalis, 2000). The tourism product consists mainly of tourism attractions, atmosphere of tourism destination, tourism facilities and services, as well as destination accessibility (Fayall \& Garrod, 2005). Therefore it is necessary for the destination to act as a tourism package and create a complex tourism product. The pricing of a destination product is determined by the pricing policy of individual stakeholders. But the DMO can control elements of pricing through regulation, advice and partnership with private sector. Product distribution is the element of marketing mix where cooperation takes a significant role. Reservation systems, where accommodation and hospitality facilities, tour operators and DMO are working together, can be a good example of such cooperation (Buhalis, 2003). The last element of marketing mix is marketing communication. As Buhalis (2000) emphasizes achieving a consensus on the marketing campaign as well as raising funds to develop and implement is one of the most challenging tasks for destination marketing.

Because many destinations offer excellent facilities and tourism services, claim that have unique culture and heritage, it is important to differentiate. Therefore creating a strong brand and quality management system will distinguish a destination and creates a unique selling proposition, which will lead to success on the international market.

\subsection{Tourism Regions}

Tourism region is a natural territorial unit, which has homogeneous geographical and geomorphological territory different from the neighboring historical and cultural heritage, historical and cultural development, lifestyle, habits, population and elements following the availability of places. This type of region is specific territory resulting from the long-term natural evolution. Therefore, its boundaries are not set out firmly or clearly and often arise spontaneously. Those regions do not have the official set of the internal configuration or internal relations, governance structures and especially no powers, responsibilities and resources for split of their existence (Nejdl, 2010).

There are seventeen tourist regions destinations in the Czech Republic, divided into forty tourist areas.

In recent years, the Czech Republic creates a system of tourism, focusing on the destination management and the destination itself (according to Bieger (2008) the geographic area, that is selected as a target by participants and dispose of the tourism attractions, infrastructure and superstructure). 


\subsection{Cultural Tourism and its Potential}

Cultural tourism can be defined as "the movement of persons to cultural attractions away from their normal place of residence, with the intention to gather new information and experiences to satisfy their cultural needs" (Richards, 2005). Authors such as Dallen, 2011 highlights that there are many possible angles of view on the terminology. The main difference of those approaches is in the "context" of the terminology not its "content". Therefore terms like "cultural tourism" or "heritage tourism" can be seen in various publications but the content of those terms is the same.

The core or the terms is always culture in different forms which can serve as mentioned cultural attractions. Nevertheless, the Czech Republic is world-known tourism destination especially because of its unique immovable cultural heritage. The number of preserved immovable cultural heritage monuments can be from the international tourism angle of view also identified as one of the unique selling propositions of the Czech Republic (exact numbers are presented in Tab. 1). According to the Tourism marketing strategy of the Czech Republic (Palatková et al., 2012), cultural heritage is one of the most important strengths of the Czech Republic in the field of inbound tourism. More than 40 thousand cultural monuments, 12 monuments listed on the UNESCO World Heritage List, as well as 272 monuments of an extremely high importance with status of national heritage monument can be found in the Czech Republic. These numbers are described in the Tab. 1, classified by the region of origin (Plzeňský kraj as a surveyed region is marked by the darker color.

As the result the immovable cultural heritage monuments or sites are very often the general part of the destination management organizations offer. These organizations on the local, regional or even on the national level focus on cultural tourism. For example CzechTourism, the national tourism organization (NTO) of the Czech Republic, plans to offer "journeys of discovery" as its main theme in 2014. This complex of tourism products consists of five separated parts exploiting a greater or lesser extent of immovable heritage of the Czech Republic.

Tab. 1 - Numbers of cultural monuments in regions of the Czech Republic. Source: National Heritage Institute

\begin{tabular}{|c|c|c|c|c|c|c|c|c|c|c|}
\hline 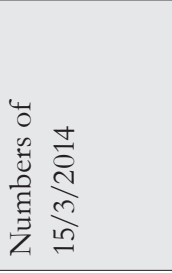 & 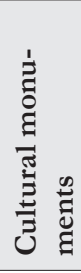 & 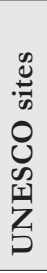 & 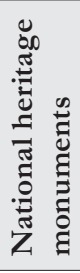 & 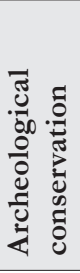 & 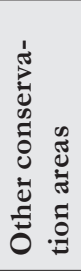 & 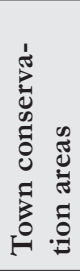 & 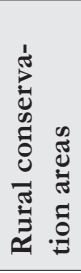 & 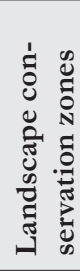 & \begin{tabular}{l}
\multicolumn{1}{c}{} \\
$\sum_{0}^{0}$ \\
0 \\
0 \\
0 \\
0 \\
0 \\
0 \\
0 \\
0 \\
0 \\
0 \\
0 \\
0
\end{tabular} & 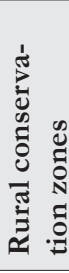 \\
\hline Praha & 2106 & 1 & 46 & 0 & 0 & 1 & 2 & 0 & 10 & 7 \\
\hline Středočeský & 4334 & 1 & 27 & 2 & 0 & 2 & 10 & 2 & 34 & 26 \\
\hline Jihočeský & 5449 & 2 & 33 & 1 & 0 & 7 & 16 & 5 & 25 & 55 \\
\hline Plzenenský & 3197 & 0 & 21 & 0 & 0 & 3 & 5 & 2 & 21 & 44 \\
\hline Karlovarský & 1402 & 0 & 10 & 1 & 0 & 3 & 2 & 3 & 11 & 8 \\
\hline Ústecký & 3507 & 0 & 14 & 1 & 0 & 5 & 3 & 3 & 17 & 13 \\
\hline
\end{tabular}




\begin{tabular}{|l|c|c|c|c|c|c|c|c|c|c|}
\hline Liberecký & 2242 & 0 & 11 & 0 & 0 & 0 & 8 & 2 & 20 & 10 \\
\hline $\begin{array}{l}\text { Královéhra- } \\
\text { decký }\end{array}$ & 2997 & 0 & 17 & 0 & 1 & 4 & 2 & 1 & 15 & 13 \\
\hline Pardubický & 2089 & 1 & 11 & 1 & 0 & 3 & 1 & 1 & 19 & 3 \\
\hline Vysočina & 3028 & 3 & 13 & 0 & 0 & 3 & 3 & 1 & 22 & 5 \\
\hline Jihomoravský & 4237 & 2 & 29 & 2 & 1 & 3 & 3 & 3 & 12 & 9 \\
\hline Olomoucký & 2188 & 1 & 13 & 0 & 0 & 2 & 1 & 0 & 15 & 9 \\
\hline Zlínský & 1439 & 1 & 13 & 0 & 0 & 1 & 3 & 0 & 14 & 3 \\
\hline $\begin{array}{l}\text { Moravskos- } \\
\text { lezský }\end{array}$ & 2077 & 0 & 14 & 0 & 0 & 3 & 2 & 0 & 18 & 6 \\
\hline TOTAL & $\mathbf{4 0 2 9 2}$ & $\mathbf{1 2}$ & $\mathbf{2 7 2}$ & $\mathbf{8}$ & $\mathbf{2}$ & $\mathbf{4 0}$ & $\mathbf{6 1}$ & $\mathbf{2 3}$ & $\mathbf{2 5 3}$ & $\mathbf{2 1 1}$ \\
\hline
\end{tabular}

\section{Monument Administration in the Czech Republic}

In the Czech Republic, legislation allows both private and state ownership of the cultural monuments. According to the legislation, all owners are responsible for preservation of the monument (Act No. 20/87 Coll The state conservation of cultural monuments). The highest state organization responsible for preservation of monuments is the Czech Ministry of Culture and its statesponsored body, the National Heritage Institute (NHI).

The NHI is a professional research organization of the state monument care. The Institute is also responsible for a set of the most valuable cultural heritage monuments of the Czech Republic with high potential for tourism. It includes more than 100 castles and chateaux with the status of the national cultural monument. The global objective of the NHI in the field of monument management is preservation and its economization through domestic and inbound tourism activities. After the reorganization process in 2013, the NHI separated professional and research activities from the others, such as management (Tittelbachová, 2011). Nowadays, the NHI realizes its activities through the regional professional offices and the regional monument management offices. These offices provide methodological and professional support of the monument owners and also coordinate activities connected with the administration of the monuments under the administration of the NHI.

\section{STUDY}

Cooperation of culture and tourism or its theoretical possibility is one of trends of the last years. Pressure on the formation of the product involving both culture and tourism sector is also highlighted by different authors e.g. Smith \& Richards, 2013 or Sigala \& Leslie, 2005. According to the facts mentioned in the introduction the main objective of this article is to identify main possibilities of cooperation between tourism industry and selected cultural monuments on the regional level. This cooperation is possible from a major part also thanks to the mentioned reorganization process of the NHI. This process has strengthened marketing possibilities of the monuments under governance of the NHI and allowed them to increase its involvement in the tourism industry. The survey used for this publication was made among managers of cultural 
monuments all across the Czech Republic. Only one region was chosen due to different destination management situation in various regions. Focusing on only one region provides better and more specific view on the tourism-culture cooperation issue.

\section{Methodology}

The first step of the research was to find an optimal region with a considerable link between tourism and cultural heritage. For the purposes of this publication, it was needed to choose a region with an active approach to the usage of culture for tourism purposes. The chosen region also needed to offer several heritage monuments with a considerable value for tourism industry.

Pilsen region was chosen due to the several different reasons.

This region is known for its huge cultural heritage potential. One of the proofs of thepotential is the Pilsen's presentation as the European capital of culture 2015. For the purposes of the study two monuments with considerable tourism potential were chosen - Plasy Monastery and Chateau Kozel.

Both of these monuments are approximately equidistant (20 kilometers) from the centre of the region - Pilsen. Both of them are under government of the NHI. Plasy Monastery is known for its unique historical and cultural value. The monastery was also proposed to be inscribed on UNESCO Heritage List it the past years. Besides its location Chateau Kozel was chosen on the basis of its high number of visitors, well diversified revenues portfolio and relatively high revenue/number of visitors figure (Tab. 2).

Tab. 2 - Statistic figures of top Pilsen region monumens. Source: Statistics of the National Heritage Institute (www.npu.cz)

\begin{tabular}{|c|c|c|c|c|c|c|}
\hline $\begin{array}{l}\text { Numbers of } \\
01 / 2014-12 / 2014\end{array}$ & 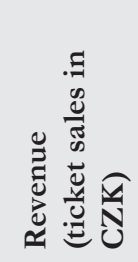 & 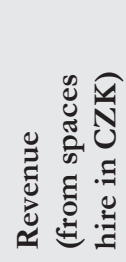 & 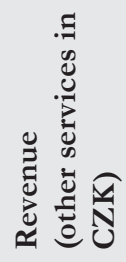 & 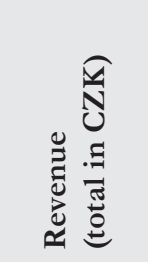 & 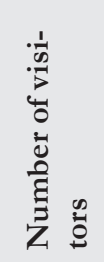 & 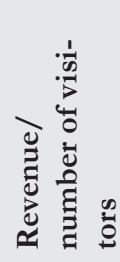 \\
\hline Rabí Castle & 2465760 & 132642 & 100768 & 2701483 & 55868 & 48 \\
\hline Kozel Chatean & 2247093 & 341034 & 50206 & 2638333 & 29930 & 88 \\
\hline Švihov Castle & 1875168 & 78128 & 594943 & 2548551 & 35532 & 72 \\
\hline Velhartice Clastle & 2158850 & 145591 & 62806 & 2367248 & 44029 & 54 \\
\hline $\begin{array}{l}\text { Kladruby } \\
\text { Monastery }\end{array}$ & 1275118 & 216839 & 66503 & 1583773 & 17013 & 93 \\
\hline Plasy Monastery & 1091470 & 279816 & 103132 & 1501037 & 16255 & 92 \\
\hline
\end{tabular}

Research is based on the questionnaire survey and guided interview conducted by the Master degree students of the University of Business in Prague in 2012 among monument managers of selected cultural monuments and also on analysis of potential made in the same year. The results of the mentioned survey are compared with objectives and planned activities of the Pilsen destination. 
The main objective of the survey was to show potential space for cooperation between selected cultural monuments in Pilsen Region that have a significant cultural national importance and destination management organization. Monument managers were asked about general problems of the tourism product creation. Next objective was to identify the critical obstacles to increase economic self-sufficiency of these monuments. Last part of the questionnaire was focused on the non-economic indicators like future plans, destination attractiveness and the quality of the primary and secondary offer in the destination. Selected results are compared with planned activities of the regional destination management (that is realizing by the department of tourism of the Regional Office). Recommended result is to find a space for cooperation among the specific activities of the regional tourism organization (RTO) and selected monuments.

\section{Pilsen Region Overview}

Tourism Management is currently not regulated enough by national or regional and local level. Form and organization of management depends on the decision of the competent public authorities (ministry, regional councils, statutory cities and municipalities). In 2010, Ministry of Regional Development re-initiated processing of the law on the promotion and management of tourism. However, government has not discussed the law yet and other activities that would lead to the completion of the law are suspended.

Pilsen Region is one of fourteen administrative regions of the Czech Republic. From the perspective of tourism there are two tourist regions - Pilsen and Czech Forest tourist region and Sumava tourist region (one part of the Sumava tourist region is located in south of the country) and three tourist areas - Sumava, Czech Forest and Pilsen. In many destinations of the Czech Republic, destination management organizations were established both at the regional level and at the level of the individual tourist regions. In the Pilsen Region (as the only one in the Czech Republic) was unfortunately not established any destination management organization. All activities including marketing provide the Department of Culture, Monument Care and Tourism within the Regional Authority of the Pilsen Region. However, several initiations to establishe the local destination management organizations have been noted (for instance in the regions North Pilsen, Klatovsko and Šmava). To their creation and start-up they need financial resources, which has not yet been in the subsidy policy of the region and Regional Operational Programs (ROP) provided. The most significant was the long-term absence of modern destination management methods during the implementation of Plzen - European Capital of Culture project. January 1st, 2014, Pilsen decided to transform the city-funded organization Esprit, which managed the cultural center and museum Patton, to the organization "Plzen - TURISMUS" as the destination management organization.

\section{RESULTS}

Monument managers marked a few planned activities in the mid-term time period. Mostly, these activities are connected with a new product offer such as gastronomical or accommodation services to widen a product portfolio. The main problems of these monuments are very different. However, connection to the product offer condition can be found. 
Tab. 3 - Results of the Survey. Source: Own creation

\begin{tabular}{|c|c|c|}
\cline { 2 - 3 } \multicolumn{4}{c|}{ Plasy Monastery } & Planned activities & Main problems \\
\cline { 2 - 3 } & Reconstruction activities & Financing \\
\cline { 2 - 3 } & New cultural products & Geographical location \\
\cline { 2 - 3 } & $\begin{array}{c}\text { New accommodation serv- } \\
\text { ices }\end{array}$ & $\begin{array}{c}\text { Only professional based } \\
\text { products }\end{array}$ \\
\cline { 2 - 3 } Chateau Kozel & New gastronomical services & Insufficient promotion \\
\hline \multirow{4}{*}{ New gastronomical services } & New technical equipment & Defunct restaurant \\
\cline { 2 - 3 } & & $\begin{array}{c}\text { Condition of surrounding } \\
\text { greenery }\end{array}$ \\
\hline
\end{tabular}

Question is how this planned activities (Tab. 3) are suitable with the planned activities by destination management organization and also, if the mentioned problems can be solved by cooperation with destination management organization. To answer this question the strategic plans of destination must be identified.

Planned activities based on presented results of the research couldn't indicate scope for cooperation by themselves. The results have to be linked to the activities of the Pilsen regional tourism organization. Next paragraph indicates the critical points in the Concept of Tourism Development of the Pilsen Region 2014 - 2020 (KPMG, 2013) where the space for cooperation can be found.

Selected cultural monuments should be linked to the specific activities of the RTO. According to the mentioned Concept of Tourism (KPMG, 2013), tourism products connected with the culture or cultural tourism are determined for mass targeting marketing activities. There can be found many suggested tourism products with the space for cooperation with cultural monuments.

"Pilsen region in the changes of history", together with other products as "Pilsen region full of experience and lessons" or "Traditional taste of the Pilsen region" can be marked as products with potential convenient space for the cooperation. The Concept also suggests the potential cooperators for realization of these products. Management of cultural monuments or its founders or owners are suggested as these cooperators for the first two mentioned products. The third one is also suitable with planned activities in the researched monuments. Cooperation on this particular product will be available as soon as these monuments will start provide a gastronomical services.

\section{DISCUSSION}

Many possibilities for cooperation can be found on basis of the conducted survey. Most of the planned activities by surveyed monuments are connected with a tourism product creation that can is suitable with planned tourism products of the whole destination. How exactly can cooperation help to solve surveyed monuments problems or how exactly can this cooperation help with the realization of planned activities describes following table (Tab. 4). 
Tab. 4 - Cooperation suggestions. Source: Own creation

\begin{tabular}{|l|c|c|}
\hline \multirow{2}{*}{ Planned product by RTO } & \multicolumn{2}{|c|}{ Space for cooperation } \\
\cline { 2 - 3 } & Plasy Monastery & Chateau Kozel \\
\hline \multirow{2}{*}{$\begin{array}{l}\text { Pilsen region in the changes } \\
\text { of history }\end{array}$} & Co-financing & $\begin{array}{c}\text { Promotion / Distribution } \\
\text { potential }\end{array}$ \\
\cline { 2 - 3 } & $\begin{array}{c}\text { Participation on products for } \\
\text { non-professional public }\end{array}$ & \\
\hline $\begin{array}{l}\text { Pilsen region full of experi- } \\
\text { ence and lessons }\end{array}$ & $\begin{array}{c}\text { Promotion / Distribution } \\
\text { potential }\end{array}$ & $\begin{array}{c}\text { Promotion / Distribution } \\
\text { potential }\end{array}$ \\
\hline \multirow{2}{*}{$\begin{array}{l}\text { Traditional taste of the Pilsen } \\
\text { region }\end{array}$} & Inclusion in the product offer & $\begin{array}{c}\text { Promotion / Distribution } \\
\text { potential }\end{array}$ \\
\cline { 2 - 3 } & & Inclusion in the product offer \\
\hline
\end{tabular}

The RTO could provide co-financing of specific projects connected with its objectives. Using specific marketing activities, it can also help to change the visitors perception of products. This way of using marketing can be essential for the Plasy Monastery issue of strictly professional based product portfolio. Probably the most common space for cooperation is the inclusion of the monuments in regional promotion materials (such as brochures). This inclusion can be very important for the monuments because it also means potential usage of the new distribution channels.

\section{CONCLUSION}

Monuments in the Czech Republic realize its own activities to economize own products. The process of economization can be realized through tourism. On the regional level the cooperation between sectors of culture (represented by monuments and its administrators such as the NHI) and tourism sector (represented by regional tourism organizations) can helps to optimize an approach of the economization of cultural heritage in the context of tourism.

This hypothesis was demonstrated on the specific example of the Pilsen region in the Czech Republic. This region with high tourism potential has no regional destination management organization. Destination marketing activities are realized by various organizations with the tourism department of the Regional Office. Although the Pilsen Regional Office has prepared the Concept of tourism development for 2014 - 2020. By comparing an objectives and recommended products of the region with an plans and problems of two selected monuments in the region (Chateau Kozel and Plasy Monastery) the space for cooperation was found.

The activities or planned activities of these two institutions are very similar. The monuments often offer products of culture of tourism products without proper promotion activities or distribution that can offer the RTO.

A complex tourism product can be created by connecting these activities or its realization to achieve a common goal of the most cultural or tourism organizations - satisfaction of visitors needs and wishes (Fig. 2). 


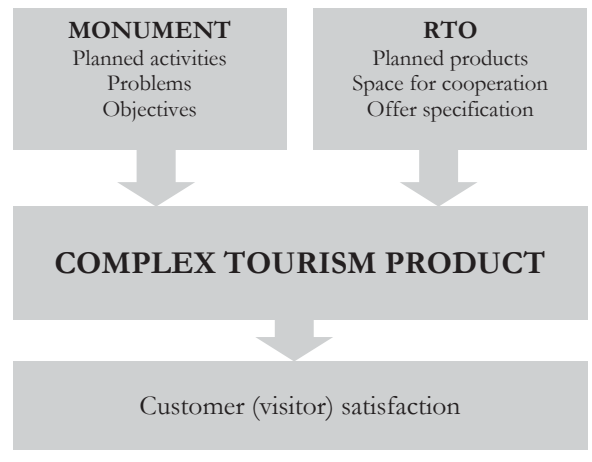

Fig. 2 - Cooperation model. Source: Own creation

Those results are just conceptual. The example of Pilsen Region can serve as an introduction to the issue of intersector cooperation between tourism and culture on the regional level. However, complex research among a huge number of monuments in the Czech Republic and analysis of related strategies to find an optimal common way for cooperation would be a suggestion for further research.

\section{References}

1. Bieger, T. (2008). Management von Destinationen. München: Oldenbourg Wissenschaftsverlag.

2. Beritelli, P. (2011). Cooperation Among Prominent Actors in a Tourist Destination. Annals of Tourism Research, 38 (2), 607-629.

3. Buhalis, D. (2000). Marketing the competitive destination of the future. Tourism management, 21(1), 97-116.

4. Buhalis, D. (2003). eTourism: Information technology for strategic tourism management. Pearson Education.

5. Dallen, J. (2011). Cultural Heritage and Tourism: An Introduction. Buffalo: Channel View Publications.

6. Fyall, A., Oakley, B., \& Weiss, A. (2000). Theoretical perspectives applied to interorganisational collaboration on Britain's inland waterways. International Journal of Hospitality \& Tourism Administration, 1(1), 89-112. http://dx.doi.org/10.1300/J149v01n01_06

7. Fyall, A., \& Garrod, B. (2005). Tourism marketing: A collaborative approach (Vol. 18). Channel View Publications.

8. Inskeep, E. (1991). Tourism Planning: An Integrated and Sustainable Development Approach. Canada: Wiley.

9. KPMG. (2013). Concept of Tourism Development of the Pilsen Region $2014-2020$.

10. Gúčik, M. et al. (2012). Manažment cielového miesta cestovnébo ruchu. Banská Bystrica: SlovakSwiss Tourism. 
11. Leslie, D., \& Sigala, M. (Eds.). (2005). International cultural tourism: Management, implications and cases. Routledge.

12. Ministerstvo kultury České republiky (2011). Koncepce památkové pécé v České republice na léta 2011 - 2016. Retrieved April, 16, 2014, from: http://www.mkcr.cz/cz/kulturni-dedictvi/ pamatkovy-fond/analyzy-koncepce-dokumenty/koncepce-pamatkove--pece-99649/

13. Morisson, A. (2013). Marketing and Managing Tourism Destinations. Oxon: Routledge, 2013.

14. Nechvílová, S., Holý, M. \& Krátký, J. (2006). Navaz̧ováni partnerství pro cestovni ruch. Pardubice: První regionální a rozvojová a.s.

15. Nejdl, K. 2010. Management destinace cestovního ruchu. Praha: VŠH, 2010.

16. Palatková, M. (2011). Marketingový manažment destinací. Praha: Grada Publishing.

17. Palatková, M., Tittelbachová, Š., \& Valská, T. (2012). Marketingová koncepce cestovníbo ruchu 2013 - 2020. Retrieved April 18, 2014, from http://www.czechtourism.cz/getmedia/ fa20d069-2d8b-4d19-8591-b19083531b33/11_12_13_marketingova_strategie.pdf.aspx

18. Pechlaner, H. et al. (2012). Destination management organizations as interface between destination governance and corporate governance. Anatolia, 23(2), 151-168. http://dx.doi. org/10.1080/13032917.2011.652137

19. Pike, S. (2012). Destination marketing. Routledge.

20. Porter, M. (1990). The Competitive Advantage of Nations. Harvard Business Review. 68(2), 73-93.

21. Presenza, A., Sheehan, L., \& Ritchie, J. B. (2005). Towards a model of the roles and activities of destination management organizations. Journal of Hospitality, Tourism and Leisure Science, 3(1), 1-16.

22. Ritchie, J. B., \& Crouch, G. I. (2003). The competitive destination: A sustainable tourism perspective. Cabi.

23. Smith, M., \& Richards, G. (Eds.). (2012). The Routledge bandbook of cultural tourism. Routledge.

24. Tittelbachová, Š. (2011). Turismus a veřejná správa. Praha: Grada Publishing a.s..

25. UNWTO. (2007). A Practical Guide to Tourism Destination Management. Madrid: World Tourism Organization.

26. Vanhove, N. (2005). The Economics of Tourism Destinations. Oxford: Elsevier.

27. Wang,Y., \& Fesemmaier, D. (2007). Collaborative Destination Marketing: A case study of Elkhart county, Indiana. Tourism Management. 28, 863-875. http://dx.doi.org/10.1016/ j.tourman.2006.02.007

28. WTTC. (2014). Travel \& Tourism Economic Impact 2014 Czech Republic. Retrieved April, 19, 2014, from http://wttc.org/site_media/uploads/downloads/czech_republic2014.pdf 
Contact information

Ing. Śárka Tittelbachová, Ph.D.

University of Economics, Prague

W. Churchill Sq. 4, 13067 Prague 3

Email: tittelbachova@vse.cr.

Ing. Jan Šrámek, DiS.

University of Business in Prague

Spálená 76/14, 11000 Praba 1

Email:jan.sramek@mensa.cr.

Ing. Gabriela Hrubcová

University of Economics, Prague

W. Churchill Sq. 4, 13067 Prague 3

Email:qhrug00@vse.cr.

Ing. Tomáš Gajdošik

Matej Bel University

Tajouskébo 10, 97590 Banska Bystrica

Email:tomas.gajdosik@umb.sk 